Article

\title{
Domination, Power, Supremacy: Confronting Anthropolitics with Ecological Realism
}

\author{
Toni Ruuska $^{1, * \mathbb{C}}$, Pasi Heikkurinen ${ }^{1}\left[\mathbb{D}\right.$ and Kristoffer Wilén ${ }^{2}$ \\ 1 Department of Economics and Management, University of Helsinki, 00500 Helsinki, Finland; \\ pasi.heikkurinen@helsinki.fi \\ 2 Department of Marketing, Hanken School of Economics, 00100 Helsinki, Finland; kristoffer.wilen@hanken.fi \\ * Correspondence: toni.ruuska@helsinki.fi
}

Received: 21 January 2020; Accepted: 24 March 2020; Published: 26 March 2020

\begin{abstract}
In this article, we study politics as domination. From our point of view, domination, especially in the Anthropocene, has had two vital components-power and supremacy. In order to dominate, one has to have power over others. In addition, the politics of domination, such as colonial oppression of Latin America, has required reasoning, justification, and legitimation, often connected to superiority (because of religion, society, or civilization) from the oppressor's end. Past and present political ideologies and programs, such as colonialism, imperialism, but also welfare state capitalism, neoliberalism and increasingly popular Green New Deal are examples of what we call "anthropolitics", an anthropocentric approach to politics based on domination, power, and supremacist exploitation. In contrast to the prevailing anthropolitics, this article discusses post-Anthropocene politics, characterized by localization and decentralization, as well as a steep reduction of matter-energy throughput by introducing a theoretical frame called ecological realism.
\end{abstract}

Keywords: anthropocentrism; Anthropocene; deep ecology; degrowth; domination; ecological realism; politics; post-Anthropocene; power; supremacy

\section{Introduction}

Throughout the history of civilization, politics has been a human-centered process. It has broadly meant the activities and practices connected to the governance of human affairs. Politics, in general, refers to a decision-making process about the most desired ends and means with local, global, and context-dependent variations, in which different interest groups interact in order to decide for things that they represent and/or are associated with. Since agrarian cultures [1], this process has ranged from very to quite exclusive, where the members of the ruling elites have made decisions for everyone else's behalf, and often at their expense. Slowly, over the course of centuries, the process of politics has claimed to become more inclusive, and now, in the 21st century, many humans are seen to have at least partial access or a possibility to participate in collective decision making [2]. Disregarding this assumed gradual increase in inter-human inclusiveness, politics is still very much about human relations. That is, humans decide for humans, without giving much thought and attention to other beings and ecosystems on Earth beyond narrow utilitarian aims.

During the past few decades, this narrow, exclusive, and anthropocentric conception of politics has been contested; for instance, it has been challenged in the fields of political ecology, environmental sociology, and political economy [3-5]. The worsening ecological crisis, which manifests in climate change [6,7], has also served as a wake-up call for some politicians and business leaders to realize that politics should not be exclusively about and for humans [8]. Especially in the light of the new geological epoch, the Anthropocene, it is clear that the realm of politics affects everything on Earth. Nevertheless, while there have been repeating calls to reform and revolutionize the human 
socio-economic organization—for instance growth-based capitalism [8-10]—human-centered political systems have prevailed and continue to gain support and widespread approval among the general public in the industrialized world.

This article claims that politics, and consequently human organization, has been (as well as largely continues to be) anthropocentric. This so-called "anthropolitics" is rooted in the domination of others, both humans and non-humans. Building on ecological realism [11-13], this article posits that the prevailing anthropocentric domination, power, and supremacy lie at the root of the ongoing ecological crisis. This article proposes that politics on all levels (from global to local) need to shift from so-called anthropolitics to post-Anthropocene politics, where the underlying drive will no longer be about domination but one of coexistence and inclusion.

Apart from introducing and developing ecological realism in relation to post-Anthropocene politics, another theoretical contribution of this article derives from the analysis of different varieties of anthropocentrism [14,15]. In addition, the article links them to the past, present, and future programs of anthropolitics (see the end of Sections 3 and 4). Anthropocentrism as a phenomenon is diverse, from which can be found ontological, epistemic, moral, and agential variants [15]. In addition to these, we want to deepen the understanding and complement the existing literature by adding spatial and temporal variants to scholarly analysis.

This article is structured as follows. In Section 2, we briefly introduce what we call anthropolitics and its proposed antidotal framework-ecological realism. Section 3 describes anthropocentrism, in the context of the Anthropocene, as a foundation for domination that entails power over other human beings and non-human beings and supremacist reasoning, justification, and legitimation that has had (as well as continues to have) catastrophic ecological and social consequences. Following this analysis and narrative, the article proceeds to describe how anthropocentrism has manifested in inter-human and non-human domination in the modern political realm. From anthropolitics, the article then turns to a closer discussion on ecological realism and post-Anthropocene politics.

\section{Anthropocentrism and Ecological Realism}

Aristotle famously remarked in Politics that human beings are political animals. Certainly, living together and coming together for joint decision-making is an apt characterization of one particular trait of the human species. This characterization surely is not exhaustive, but is it even an exclusive trait? An ant colony could be seen in this way as well, as could a pack of hyenas hunting and living together. But humans do differ, at least to some extent, from the rest of the animal kingdom in their ability for utopian thinking, negotiating different abstract future scenarios, and executing their collective plans by means of technology. Another distinctive feature in human organization is an ever more global and complex social realm that surrounds the phenomenon of politics. This realm, comprising of a multitude of social and political institutions and ideologies, has developed from organic societies (with limited division of labor and hierarchy) to industrial civilization marked by an extensive division of labor, socio-economic inequality and hierarchy [16]. Particularly in the context of city-states, a more careful way to characterize politics would be to argue that it is and has resembled a process of (class) struggle or a game of power. In this process, certain individuals, classes, and interest groups have sought to seize power and authority in order to rule and dominate other humans and non-humans for the benefit of this fraction often with supremacist reasoning, justification and legitimation. This diagnosis connects to the Nietzschean proposal of will to power, which is coupled with will to transform the biosphere [17] in order to extend domination (largely by means of increasing economic wealth).

It is evident that in the Anthropocene [18], the human species is the dominating animal, indicating that humans have the possibility and power to dominate others-an opportunity, which some humans use remorselessly and ruthlessly. In the age of human domination of the Earth, the scale of the human-induced natural destruction affects the living condition of almost all earthbound beings [6,19]. While these scientific findings are correct, it is important to add that it is a rather small portion of humans and their organizations, such as oil companies and other transnational corporations and 
particular nation states [20-23], which have been in the forefront of planning and implementing these destructive acts. From this critical observation, we can be deduce that the anthropogenic changes in the biosphere are also sociogenic [15]. In other words, they point to certain individuals (historically, and still today, mostly men), social order, and specific power relations and structures, as well as to particular economic organization [24-28]. This is the background of anthropolitics, where a powerful minority of humans dominate human and non-human beings for the assumed benefit of this minority.

To confront anthropolitics, a theoretical framework and philosophical lens is introduced in this article to discuss post-Anthropocene politics. This approach is called ecological realism. It draws its inspiration from various fields and traditions of thought, such as critical realism [29], historical materialism [7,30,31], deep ecology [32,33], and (eco-)phenomenology [34-36]. In ecological realism (see Section 4 for a more detailed portrayal), nature is not reduced to a resource, but sustainable life on Earth is rather based on ecocentric being, values, activities and practices. By adopting ecological realism, anthropocentrism is studied in relation to ontological questions (what exists, what is?), epistemological questions (what kind of knowledge we can have from nature, what kind of knowledge and science there is?), and axiological questions (what needs to be done to alleviate the ecological crisis, what is good and right, what is equality and what kind of actions lead to it?), as well as in connection to question of agency and space-time. In short, ecological realism could be considered as a framework for sustainable organization of human activities, i.e., a rough sketch to inform how humans should ideally act as particles of the greater whole, disregarding how we consider the nature of human beings and their behavior (rational, irrational, or something other).

According to ecological realism, humans are not superior to the rest of nature but are a species among others. Nature exists regardless of humans, and things happen in nature disregarding humans and their existence. Nature is not dependent on humans, although humans are dependent on nature [11]. Moreover, humans have their own distinct way of perceiving, acting, and being in the world, like other species do, and the consequences of human activities can be analyzed and estimated in relation to other species, non-living nature, and ecosystems (if only partially). In addition to these, human history has been, for instance from the point of view of economic and technological development, a cumulating and culture-dependent process, which is and has been utterly entangled and embedded within natural processes, which set the limits and frame for human activities and to their quality $[7,31,37]$. Accordingly, and in contrast to the current situation, human activities have to be in proper, sensitive and interactive relation to the non-human world, because all beings have the right to flourish and the right to species-specific life on Earth [11,33]. This does not, however, entail that ecocentric thinking and activities subscribe or lead to ecological determinism [38], reductivism [39] or mysticism [16], but the aim is rather to develop a holistic and processual way to conceptualize nature and frames for human activities and organizing [40].

Before we move on to anthropocentrism, we would like to note in agreement with Malm [7] that a single theoretical framework or its development does not necessarily solve ecological or societal problems; however, this does not mean that their development would not be worthwhile. In contrast, by offering a critique and alternative approaches to existing theories and concepts, we may be able to reach and discuss some of the problems that lie in contemporary academia and in current social theory and analyze their ecological and political ramifications. In other words, critique, theory, and theoretical work may contribute to fostering and formulating alternative practices and steer them toward ecological sustainability. The work on ecological realism is hopefully part of this process.

\section{Anthropocentrism}

In the political debates and discussions on the Anthropocene epoch [19,41,42], nature is seen primarily as a standing reserve or a resource pool to serve a wide variety of human technological and economic endeavors $[9,17,43]$. This kind of instrumentalism, a utility-based relation to nature, does not seem problematic from the dominant anthropocentric worldview [44] as nature is assumed to exist for 
humanity's sake [14]. However, this kind of human supremacist standpoint has been claimed to result in existential problems, such as climate change and the sixth mass extinction event [11,14,32,45-47].

An instrumental take on nature $[9,43]$ has developed and intensified over the course of past centuries, which means that it originates from somewhere. Some events, historical developments, and culture-specific factors have influenced the human condition in such a way that, especially in Western cultures, human beings have been seen as separate and supremacist creatures from the rest of nature $[45,48]$. Even though it is difficult to differentiate these events and cultures specifically, that is, to argue from where exactly the instrumental perception of nature originates or "takes over," it is possible to locate it, at least to some extent, to humanist thinking and philosophy. Charles Taylor describes, in his book A Secular Age [48,49], a historical and cultural turn that he believes has led to the current human-centered and humanist culture. This turn took place in the beginning of the modern era, during the 17th and 18th centuries. According to Taylor, there was a shift in human thinking and self-understanding in relation to God and nature to what he calls Providential Deism: God's kingdom was not considered "ready" anymore, but unfinished and it was up to humans to make it whole again. In addition, there was a shift in focus and objectives, as the focus from divine and transcendent turned towards the mundane and ordinary: God's will was now considered to be in human flourishing. This turn, for Taylor [48] (p. 18) paved the way to secularism or exclusive humanism as he calls it, i.e., 'humanism accepting no final goals beyond human flourishing, nor any allegiance to anything else beyond this flourishing'. This entailed that humans began to perceive themselves increasingly as creators alongside God, or as continuators of God's creation, which arguably led to supremacist and separationist view of nature. Industrial and scientific revolutions then continued and amplified these developments by giving humans powerful resources and instruments to dominate and control each other and their extra-human nature [45].

Humanism, as a tradition, has been criticized extensively by some of the leading Western scholars [50-53]. Instead of discussing this critique, we want to emphasize the anthropocentric nature-relation in the humanist tradition. A common notion to both Lynn White Jr. [45] and Charles Taylor $[48,49]$ is their attempt to explain why particularly in the Western civilization humans and nature have been seen as separate entities. In addition to this, they have sought to characterize nature-relation in Western cultures through instrumentality, domination and "economic value". In addition to these important contributions, anthropocentric perception of nature has been argued to be part of the Western philosophical tradition as well, for instance in Plato's Timaios dialogue, or in Descartes' body/mind dualism [40,54], and especially manifested in Bacon's instrumentalism [49] (pp. 230-232), [7] (pp. 209-210).

Famously, White Jr. [45] was among the first to link the root cause of the ecological crisis to anthropocentrism, which he saw deeply rooted in the Judeo-Christian theology and its underlying tradition of domination and supremacy. Devall and Sessions [44] took on their behalf White's ideas further as they identified anthropocentrism as the dominant worldview of industrialized societies. They [44] (pp. 65-66) wrote that "For thousands of years, Western culture has become increasingly obsessed with the idea of dominance; with dominance of humans over nonhuman Nature, masculine over feminine, wealthy and powerful over the poor, with the dominance of the West over non-Western cultures."

Krebber [55] (pp. 328-329) claims that, as productive forces developed, the alienation of humans from nature increased: 'The distance between culture and nature, mind and matter, subject and object, human and animal, grew until humans arrogated themselves the right to be above nature and finally broke the bond.' In his book Eclipse of Reason, Horkheimer [56] (p. 169) describes this development in history as reason infested by a disease pointing to instrumental reason seeking to manipulate and dominate nature. According to Horkheimer, instrumental reason has opted to adjust nature to meet human needs and aims, instead of seeking conformity with it, as it did in the past. Bacon [57] (p. 197) has famously crystallized this sea change in 17th century in following way: 'Let the human race only be given the chance to regain its God-given authority over nature, then indeed will right reason and true religion govern the way we exert it,' while later adding that nature should serve 'human affairs 
and interests' [57] (p. 329). Furthermore, Horkheimer and Adorno [58] (p. 1) wrote in Dialectic of Enlightenment that enlightened reason has 'aimed at liberating human beings from fear and installing them as masters.' This "reason" seemingly stems from the notion that nature is perceived as hostile to human life, which is then to be conquered, controlled and dominated in order, and paradoxically, to sustain humans [55] (p. 334).

Domination and modification of nature have extended vastly in their scope since the days of Bacon as even the weather system is now targeted for manipulation [55] (p. 331). Indeed, the instrumental perception of nature has been intensified by productivist economics and growth-based politics, as well as with the wide-range utilization of fossil fuel infrastructure, which require extensive and expansive use of natural resources [23,40,59]. In Krebber's reading [55], Horkheimer and Adorno describe the modern era in Dialectic of Enlightenment as continuous struggle for the mastery of nature, in which thinking and reason function as primary means to achieve this goal. Compared to pre-capitalist and pre-modern domination, along with European Enlightenment and scientific revolution, a change in technique occurred that laid the ground for an expansion in massive scale in human's ability to control and manipulate nature. Whereas control of nature was previously approached through imitation (mimesis), nature was increasingly reduced to mere material reserve for satisfying human desires and needs [55]. Not even Marxism—probably the most prominent strand in humanist though in criticizing capitalism - has offered systematic critique, not to mention change of agenda, to anthropocentric domination of nature, as Marxist theory, research and politics have largely been in favor of industrialization and modernization committed to the ethos of progress and technological development [60-63].

It is important to remark, however, that not all humans are dominators equally. A more accurate way to put this would be to discuss of degrees of domination. Anthropocentrism should thus be seen to represent the human will or tendency to dominate [64] (p. 10), and its enactment: the domination. This tendency might be understood theoretically and psychologically as a trait that all humans may share-with different degrees in it-whenever humans see or find themselves as "better", "superior", "above", or "separate" from others (humans or non-humans) for whatever reason [14] (p. 309).

The enactment of domination has often been based on supremacist reasoning and justification. To be sure, other factors have influenced the relations of oppression as well, that is, slave trade might have been justified with supremacist arguments, but the primary reason for it was, arguably, monetary gain. Another point to consider is the fact that domination does not need to be justified in every case, especially when relations of oppression have been institutionalized (e.g., legislation concerning slavery, racial segregation, or gender discrimination). However, what domination always requires is power, that is, the will or tendency to dominate, as such, does not do anything if it is not coupled with power over something or someone. If humans do have the will or tendency, it is only, in fact, the power over something and/or someone that provides humans the ability and possibility to dominate. This power can be, for instance, political, technological, or muscular. In the Anthropocene humans dominate each other by means of wealth, military force, and with various political arrangements, and the non-human world especially by utilizing fossil-fuel-powered technology $[15,23,27,28]$.

If we conceptualize anthropocentrism in this way, it is clear that we cannot dismiss inter-human concerns from it. This is because anthropocentrism is clearly a rationale, which some humans or interest groups adopt for their purposes [14] (p. 313) and thus, anthropocentrism 'does not put human beings at the center of the universe but only certain humans: those who, for one reason or another, choose to dominate others.' In more elaborate terms, de Jonge [14] (pp. 310-311) explains that

Whatever class of social actors one identifies as being most responsible for social domination and ecological destruction (e.g., men, capitalists, whites, Westerners), one tends at the most fundamental level to find a common kind of legitimization for the alleged superiority of these classes over others and hence, for the assumed rightfulness of their domination of these others. Specifically, these classes of social agents have not sought to legitimate their position on the grounds that they are, for example, men, capitalists, white, or Western per se, but 
rather on the grounds that they have most exemplified whatever it is that has been taken to constitute the essence of humanness (e.g., being favored by God or possessing rationality).

By placing inter-human concerns at the spotlight of ecological problems does not mean that we are being anthropocentric. This should rather be considered as a focus, a fruitful starting point for understanding why humans dominate each other and non-humans, as well as to ask where the grounds for this are [14].

Now, if it is posited that anthropocentrism is a foundation for human domination, there also might be a need to extend the analysis to highlight different variants of anthropocentrism in order to deepen our understanding of the phenomenon. Heikkurinen et al. [15] review and distinguish ontological, epistemic moral, and agential anthropocentrism. In this article, two other variants are suggested to anthropocentrism, namely "spatial" and "temporal" (see Table 1). As noted by Heikkurinen and his co-authors, some social science-based Anthropocene discourses represent ontological anthropocentrism, which suggests that the existence of entities and beings on Earth are dependent on humans. In other words, existence and being are supposedly tied to language and human perception [7] thus indicating ontological exclusiveness for humans.

Table 1. Varieties of anthropocentrism.

\begin{tabular}{|c|c|c|}
\hline Variant & Main Assumption & Reasoning Based on \\
\hline Ontological & Existence is contingent on human existence & Ontological exclusiveness \\
\hline Epistemic & Humans (or certain humans) are exclusive evaluators & Epistemic superiority and utilitarianism \\
\hline Moral & $\begin{array}{l}\text { Only humans (or certain humans) possess moral } \\
\text { value }\end{array}$ & Moral superiority and exclusiveness \\
\hline Agential & $\begin{array}{l}\text { Humankind is an agent or only certain humans have } \\
\text { (proper) agency }\end{array}$ & Agential exclusiveness, superiority and speciesism \\
\hline Spatial & Earth is a space for humans & Exclusiveness, superiority and instrumentality \\
\hline Temporal & Time is human time & $\begin{array}{c}\text { Linear time, human rhythms, urgency and } \\
\text { developmentalism }\end{array}$ \\
\hline
\end{tabular}

Epistemic anthropocentrism [15], in contrast, considers humans, or alternatively only certain humans, as the only source of value, or rather exclusive evaluators, thus accompanying them also with the "right" to make decisions from everyone else's behalf, namely because the others are not assumed to possess, for example, knowledge or understanding of what is best for them. From our point of view, this type of thinking often involves a following utilitarian reasoning: if a certain activity is thought to produce utility to a certain interest group, or to a society, nation, species, bioregion, technology development, etc., then this action is considered to be legitimate. In contrast to these two, moral anthropocentrism differs from them as humans, or alternatively only certain humans, are thought as the only ones possessing morality, or the only ones that possess inherent moral value among beings [15].

Agential anthropocentrism then has its focus on agency. On the one hand, it treats humankind as an agent, which can be considered problematic from an inter-human perspective, if not complemented with a culturally sensitive understanding on agency. Categorizing the whole human species into the same group overlooks historical context, class, power relations, and ecological impacts of individual humans, organizations, and different economies [15]. On the other hand, agential anthropocentrism may suggest that some humans are more equipped and superior agents than others (e.g., men over women, or civil over indigenous). Agential anthropocentrism may also falsely indicate that only human beings are capable of rational and/or cognitive behavior.

Spatio-temporal anthropocentrism refers to seeing time and space merely in human terms. Therefore, this approach is likely to lead to favoring human activities in terms of space and time. Spatially, the Earth and beyond are considered as space for humans. Humans currently occupy most of the habitable land on Earth for agriculture ( $50 \%$ of all habitable land), forestry, mining, infrastructure and dwelling [65-67]. Humans have also historically have made claims for ownership and passed laws to appropriate land exclusively to the use of humans [68-70], which of course neglects all other species. 
Also, the outer space is increasingly conquered and exploited by humans. Spatial anthropocentrism is, in the Anthropocene, one could say, complete and ubiquitous as one species dominates the use, ownership, and control of space, however, with much disproportion in inter-human organization and impact [71,72].

Besides the spatial element, temporal anthropocentrism is about considering time as human time. It guides and encourages specific actions with an anthrotemporal justification. Eco-modernist thinking and activities could be thought as an example of temporal anthropocentrism, that is, when humans seek solutions for example to alleviate climate change by relying on nuclear energy and other modern complex and resource-intensive technologies, these solutions are often legitimized by pledging to a sense of urgency to transform nature [17]. Another example of temporal anthropocentrism would be to perceive human nations and organizations following a certain type or path of linear temporal development to a supposedly higher stage of progress, for example from hunting and gathering to agriculture, to justify domination.

\section{Politics of Domination}

In critical political theory, e.g., Marxism [10] and world-systems analysis [2], politics is commonly understood as a process of struggle, where different classes, interest groups and those in power seek to fulfill their economic, social and ideological objectives. As Wallerstein [2] (p. 51) writes, there is a constant struggle over the allocation of the surplus value in the current capitalist world-system. In this class struggle, states have been central actors ever since the French Revolution, which brought two essential changes to the modern political order. The first one was political expression of the theory of progress, very much in line with the Enlightenment. The second was modern conception of sovereignty, which stripped absolute power from monarchs and transformed it into the legislature of the people [2]. Since then, politics have very much been about exclusion and inclusion: 'Those who were excluded sought to be included, and those who were already included were most often inclined to keep eligibility for citizens' rights defined narrowly, maintaining the exclusions' [2] (p. 52).

More generally, unequal power relations, for instance concerning indigenous livelihoods, the ownership of the means of production and allocation of surplus value, have produced recurring conflicts in which the people in power have attempted to dominate others [5]. Colonialism, imperialism, and neoliberal capitalism, for instance, could all be considered as manifestations of a dog-eat-dog world, in which the process and the outcome have been similar through ages-that is, conquest, domination, and exploitation of others. Also, the legitimation and justification of domination has remained quite the same, although it has had historical variations. Supremacist arguments regarding the conquest, domination, and exploitation of indigenous peoples have altered from "civilizing mission" to "progress" and "development," the exploitation of the non-humans has shifted from conquest and colonization to utility. In short, for humans, modern civilization has meant exploitation and homogenization in the name of civilization and progress, and for non-humans, it has mean instrumentality, commodification, and destruction due to alleged human superiority.

Below, we illustrate anthropolitics the modern era by highlighting on what grounds people, nations, and dominant classes have claimed their superiority and exploitation. This analysis is by no means comprehensive, but rather, it is an illustration of anthropocentrism, its reasoning, and its justification and legitimation.

The Spanish colonization of the Americas in the 16th and 17th centuries gave rise to a theological, political and ethical debate concerning the use of military force to acquire control over foreign lands [73]. This debate occurred in the framework of religious discourse that sought to legitimate the conquest with arguments of conversion and "salvation" of indigenous peoples. The British colonizers later used similar civilizing mission argument in the 19th century, for instance, in India. In the Americas, the Spanish conquistadores explicitly legitimated their actions in terms of religious missions, by bringing Christianity to the native peoples (cf. epistemic, moral, and agential anthropocentrism). Innocent IV, among others, argued that the use of force was legitimate if the indigenous peoples 
violated the so-called natural law, which led the Spanish to conclude that the habits of the natives, from nakedness and unwillingness to labor, were demonstrations of this inability [73].

In contrast to many influential philosophers, Diderot was one of the most vigorous critics of European colonization. For one, he challenged the common view that indigenous people benefitted from European civilization, and did not consider non-Westerners as primitive, nor more complex forms of social organization as superior. He also claimed that traders and explorers had no right to access fully inhabited lands- "the right to commerce" was commonly used as a justification by Spanish thinkers in the 16th and 17th century [73] (cf. spatial anthropocentrism). In contrast to Diderot, several influential philosophers, for instance in France and England in the 18th and 19th centuries took entirely opposite view and assimilated some version of the so-called developmental approach from the Scottish Enlightenment. According to it, all societies naturally transformed from hunting, to herding, to farming, to commerce; or from "savagery" to "barbarism" and to civilization, where the term civilization marked the highest point of (moral) progress [74] (cf. moral and temporal anthropocentrism).

The language of civilization, savagery and barbarism is common to many 18th and 19th century thinkers, including Karl Marx and John Stuart Mill. Mill thought that "savages" did not have the capacity for self-government (cf. epistemic and agential anthropocentrism). He thought that only commercial society could offer individuals a possibility to realize their potential for freedom and self-government, thus leading to a conclusion that colonizing states are acting in the interest of the less-developed peoples by governing them [73] (cf. moral and agential anthropocentrism). Marx also had similar ideas to civilizing mission thinking, so typical for Western Enlightenment and Eurocentric viewpoints, as Traverso [75] (p. 156) writes. Marx considered the colonial world as the periphery of the West, and opined that the West would determine its evolution, because of its own political orientation was "regressive" and "immature" [75] (p. 157). In articles written in the 1850s, Marx deals with the British imperial conquest in India and China, where he stigmatizes the violence of colonialism but does not put into question the legitimacy of British conquest in the name of a "superior civilization" (cf. epistemic, agential and temporal anthropocentrism). Marx writes that the British Empire acted as 'an unconscious tool of history' in India, and its mission was at the same time destructive and regenerative [75] (pp. 158-159). Similarly, Kohn and Reddy [73] note that Marx's thinking of British colonialist domination reflects the same ambivalence that he and Engels have in The Communist Manifesto toward capitalism: 'Marx recognizes the immense suffering brought about during the transition from feudal to bourgeois society while insisting that the transition is both necessary and ultimately progressive.'

From Tocqueville's thinking can be found more direct and exclusive political reasoning regarding domination, as he asserted that French colonies in Algeria would increase France's status in relation to its rivals. Unlike the proponents of the civilizing mission, Tocqueville noted that the brutal military occupation did not introduce good government or advanced civilization, but quite the opposite. Instead, he saw the French national interests as paramount and moral considerations subordinate to political goals [73]. Tocqueville's line of thought can also be considered to reflect the modern geopolitical power relations, where different nation states, economic organizations and other agents of capital are seeking to further their economic and political interests often at the expense of others [2,76].

From the late 19th century, anthropolitics and its underlying domination shifts from supremacist reasoning towards economic and political utility, as imperialism and colonialism change form due to capitalist and nationalist competition. In Imperialism: The Highest Stage of Capitalism [77], Lenin famously reinterpreted the term imperialism to refer to the age of concentrated capital and competition between nation states and their corporations. As Foster [78] explains, this new imperialist stage, beginning in the late 19th century was seen by Lenin as an outcome of growth of gigantic capitalist firms, which often had monopoly power, and the close connection they had to nations states from which they originated. This development resulted to the nationalist struggle to control and utilize the 
human and non-human beings and natural resources at the global scale, leading to inter-capitalist and nationalist competition and eventually to two world wars [78].

In general, Marxist scholars are quite unanimous on the notion that imperialism is inevitable result of capitalism $[28,77,79]$. This is because expansive capital accumulation is found to lead in constant search for new markets and opportunities for further accumulation, as already Marx and Engels foresaw in The Communist Manifesto [79]. As Moore [27] (p. 87) writes, capitalism repeatedly 'exhausts its sources of nourishment,' pertaining that capital accumulation depends upon finding new frontiers for appropriation. Hence, capitalist relations of appropriation eventually extend their grasp to novel territories by bringing industrialization and imperialism alongside with them [27] (p. 101).

In the 21st century, after many centuries of colonialism, imperialism, and capitalist appropriation in the name of progress, development, Christ, civilization, and affluence, the ecological impacts of humans' unequal affluence are indeed shocking. As a consequence of the "great acceleration" [80], every major ecosystem on Earth is in decline [9] (p. 46). A focal problem for ecological sustainability is that nature is perceived, in this era and in capitalism, not only as a limitless external entity, but also as barrier among others to be transcended, but above all as a resource to be exploited [27] (p. 95). Moreover, a reason why, for example, many of the citizens in affluent industrial societies are not able to see the full human dependence and embeddedness in nature, seems to be linked to their overall consumerist lifestyle, and capitalist economics and politics, which give the accumulation of wealth (or economic growth) the first priority in societal goal setting [9] (see ontological, epistemic and agential anthropocentrism). Indeed, as Krebber [55] (p. 333) aptly puts it: "the very idea of being in tune with nature in Western, capitalistic thought, is self-evidently equal to the subjugation of nature."

The subjugation of nature to human needs, wants and desires has been equal also for the later phases of capitalism in the 20th and 21st century. Although, the unprecedented economic growth in the post-war years resulted in a few somewhat successful examples from the human point of view, these manifestations of welfare capitalism, for instance the Nordic welfare states, were by no means free or excluded from global relations of oppression and capitalist competition, not to mention their ecological destructiveness. The Nordic welfare states, for example, were built around economic growth and expansive exploitation of natural resources, which meant that they reproduced the same instrumental outlook on non-human nature as their predecessors did, albeit with more equality and inclusion between humans [81] (cf. epistemic and spatial anthropocentrism). Yet, in front of the ecological crisis these societies have proven as incapable as every other industrialized society to shift their course from ecological devastation to sustainability [82]. Instead of changing the course to the needed degrowth policies and economics [83], the response is similar to other nations and transnational corporations: daydreaming about clean technology and ways to decouple economic growth from ecological impacts in the future. As Kolakowski [10] (p. 1180) fittingly noted, "The situation is one of a kind frequently met with in history, where people feel they have got into a blind alley: they long desperately for a miracle, they believe that a single magic key will open the door to paradise, they indulge in chiliastic and apocalyptic hopes."

For the last four decades, the politics of welfare capitalism have been overtaken by politics and economics of neoliberalism [76,84]. Neoliberalism has been both an ideology for the ruling elites and an instrument for transnational capital and its agents [59] (p. 93). On the one hand, neoliberalism has been an ideological and political campaign claiming that private sector is more effective than the public sector. Neoliberal policies have favored "free trade," financial de-regulation, as well as re-regulation, big banks and transnational corporations, and the so-called trickle-down economics. On the other hand, neoliberal politics and economics have targeted the internal problems of capitalism by seeking to rearrange the global political field of accumulation and economic markets to favor the movements of transnational capital, by securing capital flows, privatizing healthcare, infrastructure, education, and by capitalizing, proletarizing, and urbanizing Asia, Latin America, and Africa. In short, neoliberal politics and economics have been used as a vehicle to secure and reproduce the rule of transnational capital and its agents [76]. In this era, the non-human nature has been subjugated, perhaps more aggressively 
than ever before, to the iron rule of private economic wealth accumulation, as the non-human world has been valued only when it has served the interests of capital and technology development $[27,28]$. In addition to this, socio-economic inequality among humans has reached its new peak in the neoliberal era $[71,72,81]$. Forty years of neoliberal politics has ravaged the blue planet and meanwhile led to a political dead-end, in which a very small minority dominates others and collects the diminishing returns from the global capitalist market economy.

Before moving on, it is important to note again that the capitalist mode of production has to expand in order to reproduce itself $[59,85]$. This implies that this productivist organization is not only in antagonistic relation to nature [40], but also to all other modes of organization and cultures, including subsistence and self-sufficiency. Capitalist appropriation started from the enclosures and plundering of the commons $[27,69]$ and has continued for the past centuries to exploit and dominate all life forms on an increasing scale, while piling up waste and ecological destruction. As Illich writes in Shadow Work [86] (p. 139), the modern era "can be understood as that of an unrelenting 500-year war waged to destroy the environmental conditions for subsistence and to replace them by commodities produced within the frame of the new nation-state." This war has been a circle of coercion and pauperization, where peoples, cultures and non-human beings are enforced to be part of the sphere of accumulation, as Snyder [87] remarks. He concludes by stating, "When the commons are closed and the villagers must buy energy, lumber, and medicine at the company store, they are pauperized" (p. 38). Where colonialism was originally justified with bibles and Christ, it continues with micro-credits, bottom of the pyramid economics and Western educational curriculum, to replace subsistence economies with capitalist growth and market economies.

The future projections of anthropolitics are manifested in initiatives such as the popular Green New Deal [88-91]. The Green New Deal (GND) gives non-empirically grounded promises of simultaneously circumventing the socio-economic inequality and ecological devastation with politics and economics of green growth $[92,93]$. This new deal does not entail the demolition of capitalism or productivism, but supposedly offers a more responsible, moderate and "green" version of it without questioning economic growth and the underlying politics of domination.

GND takes its inspiration from Roosevelt's New Deal from the 1930's, which aimed to lift the US economy from the Great Depression. In short and in contrast to New Deal, GND seeks to solve the climate crisis and socio-economic inequality with huge investments in renewable energy, energy efficiency, and clean transportation, while keeping wage levels and benefits intact [90] (p. 30). The GND is by definition a growth and reflating program, which is destined to produce more wealth, increase the standard of living, and to make the US the center of world's manufacturing again $[88,89,91]$, although some prominent public figures have also called for curtailing consumption and the overall consumerist culture [90] (pp. 264-265).

Overall, the GND seems to rely extensively on the myth of decoupling, i.e., to the idea that the ecological impacts could be decoupled from economic growth [92,93]. In this sense, GND does not vary much from other modern green capitalist economic agendas, although the reduction of socio-economic inequality is a key component of it. However, questions of equality are only extended to the human realm. One indication of this is the sense of urgency, which is also one of the key selling points of the GND, as Klein [90] (p. 33) [91] amongst others notes: "we need every action possible to bring down emissions, and we need them now." This type of rhetoric is emblematic to temporal anthropocentrism - a type of thinking where time pressure is used to legitimate vast transformations in the biosphere [18]. Indeed, the most striking feature of GND politics is the mere absence of the non-human world. When Klein [90] (p. 53), for instance, declares that let us forge GND for everyone this time, she clearly means only humans, as if human well-being would somehow be independent from the rest of the nature. 


\section{Post-Anthropocene Politics and Ecological Realism}

'As sure as impermanence, the nations of the world will eventually be more sensitively defined and the lineaments of the blue earth will begin to reshape the politics. The requirements of sustainable economies, ecologically sensitive agriculture, strong and vivid communal life, wild habitat—and the second law of thermodynamics—all lead this way.' [87] (p. 47).

In order for us to imagine an alternative mode of politics, which is capable of leading us out of the Anthropocene epoch, it is necessary to disengage from the anthropocentric ethos of Western thinking [15]. Instead of building political agendas on ungrounded optimism about human skills, technology development and dangerous productivist ideals limited to human purposes (as in the GND for instance), post-Anthropocene politics rooted in ecological sustainability must emerge. Focusing on inter-human relations clearly neglects the relevance of extra-human relations in both epistemic and axiological senses, but also from an agential perspective [15]. In contrast to this, and while a reality independent of humans is presumed [33,94,95], non-anthropocentric ethics, philosophy, and agendas [96] are essential in the search for ecological politics and economics rather than the prevailing techno-optimism and productivism.

In ecological realism - as a framework for ecologically sustainable post-Anthropocene politics and sustainable human organizing - nature is considered as a whole hosting all earthbound beings, bioregions and ecosystems. Nature does not reduce to any perception or discourse nor can be captured by any piece of writing since words and language only reach a part of the totality [33,34]. Conceptions of nature have historically often been place- and culture-dependent, even if it can be argued that all beings (such as grizzly bears, humans, basses, vipers, deer flies, silver birch, sun flowers, etc.) also share an experience of existence (whether it is being, doing, or something other). While these experiences vary in spatio-temporal context not limited to human space-time, the experience of nature and existence is arguably distinctive for humans in the Antarctic than it is from polyergus' point of view in the Amazon rainforest.

Humans have not had a particular or unitary conception of nature. Although it may be problematic to argue that a certain conception of nature has resulted in the ecological crisis, it can nevertheless be assumed that certain conceptions of nature (and consequently approaches to politics and economy) have supported or assisted the crisis more than others have, as well as prolonged its continuance. As an alternative to an anthropocentric approach, which we have argued to have led or assisted the events and activities that have produced the present ecological crisis, we present here a short summary of the key elements of ecological realism. Our interpretation of ecological realism [97] relies on critical realism [29], historical materialism [7,30,31,98], and deep ecology [11,32,33], but is also influenced by (eco-)phenomenology [34-36] and strong sustainability studies [99]. Based on these traditions and lines of thought, we have built a synthesis, which we apply in this article for outlining post-Anthropocene politics.

According to ecological realism, nature and its ecology exist in the absence of humans. Humans can obtain knowledge and information about nature, even if only partial and only subjective kind (to be sure, some understandings are considered more subjective than others). Nature's material, historical and biophysical processes set limits and frames for human activity. Within this frame and space of nature, humans have developed, in course of time, techniques and technology, and various political structures, as well as various modes of economic organizing, such as subsistence economies, feudal societies and fossil capitalism. As a general rule of thumb in ecological realism, human activities should be in an ethically inclusive and sensitive relation to rest of nature. By relying to these rather broad principles, we next present further tenets of ecological realism, a mixture of ontological, epistemological and axiological premises.

\subsection{Embeddedness, Equality and Dependency}

Nature and its ecosystems are finite entities [99-101]. Each part of each ecosystem is dependent on the whole [33]. Nature as a whole does not reduce to a part, which also means that nature, as a 
whole, is more important than its individual parts [11]. This includes humans who are embedded in the whole of nature. Humans are only a single species among other species-as important as the others, but not more or less important than the others. As human cultures receive a wide-variety of life sustaining things from ecosystems, such as air, water, soil, minerals, animals, plants and microbes [102], humans are matter-energetically dependent on the web of ecosystems, the whole of which nature consists of. More or less independent parts of the whole, such as a flock of birds or a human tribal community, are internal parts of a particular ecosystem, which makes them dependent on the whole for their survival. The ecosystem itself, however, is not dependent on its individual parts, which signifies a hierarchical relation between the part and the whole [11,15]. To be sure, human activities affect ecosystems, but the relation is asymmetrical-humans can have an effect on the climate by burning fossil fuels, which means that there is interaction between different entities, but this does not make the climate dependent on humans [7].

\subsection{Historicity, Materialism, and Specificity}

History is a matter-energetic process, as all earthbound phenomena are. Artefacts that are built today are likely to exist tomorrow, unless they are systematically destroyed. Even this will leave a thermodynamic mark in the closed Earth system. The universe also exists matter-energetically, while going through different phases, consisting of different and more or less tangible substances and compounds. Human history has co-evolved and co-developed in interaction with the non-human processes of the blue planet and its biosphere [37]. This has been a cumulative and matter-energetic process: existing generations have utilized the knowledge, skills and tools of former generations and developed or sustained them and then passed them on to the generations to come.

A focal characteristic of the human species is its capability and drive to manufacture tools for the search, cultivation and harvesting of food, habitation and clothing, as well as to make various artisanal objects to be part of social and cultural gatherings [7,98,103]. Although some other animals utilize simple tools in their activities, humans are the only ones that manufacture tools by combining different substances, and the only one who makes tools to make other tools [7] (pp. 165-166). In addition, the use of tools and the accumulating material flows are tied to a complex human-to-human interaction, as well as require high abstraction. When manufacturing and using a particular tool or natural resource, the shape of it, its form and purpose have been designed in advance. The more complex human organizations are, the more abstract the language games behind these designs. From these remarks, we can gather that, even though humans are a species among others and embedded and dependent on the surrounding ecosystems, humankind has its own specific ways of perceiving, being, and doing and a history with a species-specific impact on them.

\subsection{Agency, Intrinsicality, and the Right for Existence}

The desirability of the consequences of human actions can be estimated and analyzed with the help of ecological realism. As the Earth's climate is largely changing due to the fossil burning actions of certain individuals and organizations [7], destructive agency can thus be located to those responsible of the burning. Most of the carbon dioxide in the atmosphere is a result from the act of (both directly and indirectly) burning the fossil fuels. As it is now commonly accepted that the climate change is anthropogenic, this also means that we need theories, concepts and methods that seeks to analyze and separate actors and processes from each other [104,105].

In addition, human activities have to be in sustainable relation to the rest of nature- that is, human actions cannot occupy space in excessive manner to build roads, cities, and infrastructure or to cultivate and harness food because the excessiveness of the current human organizing pushes ecosystems and other beings towards collapse and extinction. Even disregarding this "call for balance" in human activities in space and time, other species do have the right to exist as they are, and for their inherent behavior and existence, as well as for flourishing [11,33]. In other words, all life forms have intrinsic value and right to exist [46]. For post-Anthropocene politics, this entails judgment and 
self-limitation [106], as humans do not have the right to reduce or destroy the diversity of other life forms with other reasons than fulfilling their primary needs and desires [107]. Based on this premise, the human organization should always be put in relation to other beings and ecosystems [11].

\section{Discussion}

To overcome the Anthropocene [15], but also domination of nature as a foundation of (industrial) civilization [16,108,109], reconciliation with the whole of nature is necessary [55] (p. 325). This, however, does not have to signify that nature and society are amalgamated, as Malm [7] notes in his critical review of post-humanist thought. While it is true that post-humanist scholarly work has been able to challenge the anthropocentrism that is prevalent in the humanist tradition, post-humanist thinking also contains elemental problems. As Malm [7] (chapter 2) notes in actor-network theory, or in hybridism, as he calls it, society and nature-or social and natural phenomenon-are mixed in each other in such a fashion that they have become "one". According to this point of view, things and wholes, such as a human being, a car, a concrete bridge and water flowing in a river are blended together into one quasi-object [104]. "Hybrid" is thus an actor-network or a collage, which is partly human-made or modified and partly of natural substance. What is striking from our point view is the fact that the effects and qualities of different parts and wholes are not systematically analyzed or separated $[104,110]$. This leads to a conclusion that there is no "society" and "nature"—only actor networks or hybrids.

According to hybridism, it is difficult to argue, which causes the climate to change, because hybridism obscures the cause-effect relations or withdraws from their analysis altogether [7]. This bears great relevance in the human-dominated geological epoch, where humans must learn to cope with their power and accept responsibility for their actions. It is vital that humans are able to estimate and analyze their actions and their ecological impacts (if only partially). It is of course true that matter-energetically nature and society are mixed and remain in constant interaction with one another [31]. The society is not external to nature, but embedded in it, which indeed, does entail a degree of hybridism. Yet, whereas hybridism is ontologically an interesting and welcomed standpoint, it is analytically problematic if the degrees of hybridity are not considered. Furthermore, hybridism also remains poorly fitted with politics and societal change if it does not distinguish different actors and actions, that is, differences are needed for making judgments and valuations [7]. Nature and society certainly are mixed, but to understand the ecological impacts of human organizations, to respect the diversity in nature, and to enable politics to change, a variety of different categories and units of analysis (including nature and society) are required [7,15,22].

In addition, ecological realism can be seen as an attempt to move beyond an either/or type of utopian thinking where humanism and post-humanism, or anthropocentrism and ecocentrism, are opposed [111]. However, this does not mean that we are sympathetic to anthropolitics or human domination in the Anthropocene, but rather, we argue that post-Anthropocene politics do not need to discard the whole humanist tradition or posthumanist hybridism on the condition that there occurs a significant shift toward more ecocentric values, practices, and structures (see Table 2 below).

Table 2. Comparison of humanism, post-humanism and ecological realism [14].

\begin{tabular}{cccc}
\hline & Humanism & Posthumanism & Ecological Realism \\
\hline Ontology & humans and nature & humans and nature mixed & humans as part of nature \\
\hline Epistemology & subject-object dualism & $\begin{array}{c}\text { actor-networks, hybrids and } \\
\text { collages }\end{array}$ & parts and wholes \\
\hline Axiology & $\begin{array}{c}\text { human specificity and } \\
\text { superiority }\end{array}$ & equality of actants & equality, specificity and inherency of beings \\
\hline
\end{tabular}

In any case, the call is to imagine, outline, and implement post-Anthropocene politics and frameworks that can guide the way out of the human-dominated epoch. From our point of view, this requires an understanding of nature and politics that is inclusive and preserves Earth's diversity. By developing ecological realism as a framework to guide post-Anthropocene politics, this article 
offers the following outline, which is based on the principles of ecological realism, and the critique of imperialism, developmentalism, productivism and the overall politics of domination:

1. Localization and decentralization: Ecologically sustainable post-Anthropocene politics is a local and de-centralized endeavor, in contrast to global anthropolitics. Whereas nation-states and other centralized political organizations have historically proven ill-suited to govern large areas of land, local and place-based (eco)cultures have been, due to their place-specific and inter-generational knowledge, better equipped to govern their activities in relation to their environment $[16,112]$. Centralized political structures naturally centralize power but are also distanced from local politics, knowledge, culture, context, and bioregion, which may lead to poor judgment and to favoring the surrounding areas of the power center.

2. Reduction of matter-energy throughput: For the sake of natural diversity and the continuation of diverse life on Earth, a key political issue to tackle is the reduction of matter-energy throughput as a remedy to the ecological overshoot of over-consuming nations and economies [72,83,113-115]. This can be done by means of policy and political steering toward negative economic and population growth. In practice, this could imply, for example, caps on consumption, large and unified conservation areas, maximum levels of income, carbon and resource throughput taxes, etc. Beyond these economic and political "fixes," the more general drive of post-Anthropocene politics is to dismantle industrial and growth-driven ways of life, indicating also the need to pull apart from capitalist and other productivist modes of organization [40].

3. Conservation and restoration of non-human habitats: Another starting point for post-Anthropocene politics would be to commit to the normative position that human activities should not destroy non-human habitats or over-crowd the planet's surface in their current intensity. Motives and rationales for this position can vary, but it seems obvious to the current anthropolitics encouraging economic and population growth is on the track to the sixth mass extinction [20,47]. To reverse this trend, the Earth needs time and space to heal. Recently, there has been discussion surrounding the 50/50 proposal [116], which is a promising starting point, but not a desired final outcome (as 50\% percent reserved for one species does not seem just or meet the definition nor biophysical conditions of diversity). Ultimately, and according to deep ecology and ecological realism, humans have accept the notion that they are just one species among the rest and thus deconstruct their colonization of the Earth.

4. Meeting primary needs and desires: It is not anthropocentric to be motivated by human needs and desires, as long as they fit to the ecological whole, i.e., human actions do not compromise the continuance of diverse life. While humans need and desire diverse nutrition, shelter, and clothing to keep warm and social interaction with fellow humans and non-humans, humans currently have and do many things that are not related to these needs and desires. There are a lot of things that do not fall into this category, which could be considered as humankind's secondary and tertiary needs and desires (such as smartphones, airplanes, oversea vacations, being a celebrity), which in the age of global capital and modern technology seem to be quite commonly shared (by those who can afford, have access to, and have an opportunity to pursue them). From the perspective of primary needs, humans can claim the right to clear a field in order to survive and dwell. This way humans may occupy habitable areas from other living creatures, but the reasons can be considered to be more legitimate when they deal with primary rather than secondary and tertiary needs. It goes without saying that all life is thus requires some killing and dying [33] but what is important here are the reasons behind killing and dying, as well as the scale of these measures. When the human organization reaches a point where human activities are not connected to the primary needs and desires, this activity can be questioned, as it is likely to occupy space from other beings. In contrast to these, the needs and desires that are actually basic and primary show universal characteristics, but are also dependent on history, place, bioregion, and culture. Thus, it is proposed here that so-called primary needs and desires-based politics could be one option to provide human cultures a framework to curtail or draw limits to consumption, 
production and secondary/tertiary needs and desires, and consequently, lead to sustainable well-being [99,117-119].

5. Reruralization and self-sufficiency: Such primary needs and desires-based thinking will draw our attention to places and times where they can be fulfilled. Therefore, and in order to move beyond a system of generalized private ownership, the access to and availability of land are among key issues for post-Anthropocene politics to tackle and reformulate. Moreover, and even if urban environments may offer a multitude of opportunities for human interaction, it is a matter-energetic impossibility to produce enough food and energy to sustain life in cities. Hence, the proposed post-Anthropocene politics should call for reruralization, and the politics of self-sufficiency.

6. Radical inclusiveness and equality: Post-Anthropocene politics is about inclusion, non-discrimination, and equality. While anthropolitics has been historically characterized by patriarchal domination and political exclusion of women and people of color, as well as non-humans, ecologically sustainable and socio-economically just politics have to be able to include a multitude and wide-variety of voices and stakeholders in its processes. Thus, politics should no longer be about seeking private interests or about advancing particular societal arrangements and ideologies but about coexistence and radical inclusiveness, which seeks to balance the needs of various beings and to conserve and regenerate the conditions of diverse life.

7. Detechnologization: In a world of almost eight billion people, it is extremely difficult to organize human activities sustainably with modern and resource-intensive technology [120]. On the one hand, the resource-intensity of modern technology and the quantity of humans on Earth denotes to a return to lower degrees of technology, and on the other hand, it implies that in future more and more work will be manual labor. Therefore, limits and thresholds are set to human economic activities both in physical and ethical sense, which leads us to conclude that the post-Anthropocene politics is about combining meaningful and satisfying life while radically decreasing the matter-energy throughput of industrial societies and reconfiguring their ethical, epistemic and ontological underpinnings.

\section{Conclusions}

Anthropocene epoch is by definition a result of anthropocentric domination. Humans have become a dominating force on Earth by dominating fellow humans and non-human beings. In other words, if (especially certain) humans or human cultures would have considered each other equal, as well as their non-human companions, it is imaginable that Holocene would still continue.

Anthropocentrism, and its central manifestation, anthropolitics, is a historical and unequal phenomenon. In this article, we have identified six variants of anthropocentrism, which all contribute to human-to-human and human-to-non-human domination through supremacist reasoning, justification and legitimation, or with economic and political utilitarianism and instrumentality. Our understanding is also that each component of the presented anthropocentrism typology has had a part to play in advancing the anthropogenic changes in the biosphere that have led the Earth to the new geological epoch.

To be able to depart from the course of destruction, alternative organizing and mode of politics are needed. In this article, we introduced ecological realism as a framework for post-Anthropocene politics and sustainable organizing, which seeks to rearrange and reconcile human activities with their fellow humans and non-human beings, ecosystems and nature as a whole.

It is obvious that the post-Anthropocene politics, proposed from the ecological realism framework in this article, do not fit together with the contemporary anthropolitics, which are mainly geared toward human interests with instrumentalism, utility, and wealth accumulation. Indeed, an effective post-Anthropocene political program is an antithesis, and hopefully an antidote, to the modern consumerism and productivism. Since ecologically sustainable politics are not possible in the current techno-capitalist political and economic structures, it makes little sense to propose reformist policy 
suggestions regarding greening the neoliberal capitalism or politics of ("green") growth. At the moment, post-Anthropocene politics are utopian politics for many, which seem to exist only in the margins and outskirts of contemporary societies. Our aim in this article has been, in addition to our attempt to portray anthropolitics as the domination of humans and non-humans, to shed more light to this margin so that it could someday become the mainstream, and thus its practices would shine and flourish more widely.

Author Contributions: Conceptualization, T.R., P.H., K.W.; approach, T.R., P.H., K.W.; writing—original draft preparation, T.R., P.H., K.W.; writing-review and editing, T.R., P.H., K.W. All authors have read and agreed to the published version of the manuscript.

Funding: Toni Ruuska has received funding for the writing of this article from the Maj and Tor Nessling Foundation.

Acknowledgments: We wish to thank the editors and anonymous reviewers of the article for their time and effort-your remarks were invaluable and helped us developing the argument. We would also like to express gratitude to our colleagues in the Limbo Collective for inspiring discussions. The paper was scheduled to be presented in Sustainability Science Days 2020 in Helsinki, but the event was cancelled due to coronavirus (an aggressive non-human agent).

Conflicts of Interest: The authors declare no conflict of interest.

\section{References}

1. Gowdy, J.; Krall, L. The ultrasocial origin of the Anthropocene. Ecol. Econ. 2013, 95, 137-147. [CrossRef]

2. Wallerstein, I. World-Systems Analysis: An Introduction; Duke University Press: London, UK, 2004.

3. Catton, W.R.; Dunlap, R.E. Paradigms, Theories and the Primacy of the Hep-Nep Distinction. Am. Sociol. 1978, 13, 256-259.

4. Eckersley, R. Environmentalism and Political Theory: Toward an Ecocentric Approach; Suny Press: New York, NY, USA, 1992.

5. Martinez-Alier, J. The Environmentalism of the Poor: A Study of Ecological Conflicts and Valuation; Edward Elgar: Cheltenham, UK, 2002.

6. Steffen, W.; Richardson, K.; Rockström, J.; Cornell, S.E.; Fetzer, I.; Bennett, E.M.; Biggs, R.; Carpenter, S.R.; de Vries, W.; de Wit, C.A.; et al. Planetary boundaries: Guiding human development on a changing planet. Science 2015, 347, 1259855. [CrossRef] [PubMed]

7. Malm, A. The Progress of This Storm: Nature and Society in a Warming World; Verso: London, UK, 2018.

8. Klein, N. This Changes Everything: Capitalism vs. the Climate; Simon \& Schuster: New York, NY, USA, 2014.

9. Foster, J.B. Ecological Revolution-Making Peace with the Planet; Monthly Review Press: New York, NY, USA, 2009.

10. Kolakowski, L. Main Currents of Marxism: The founders, the golden Age, the Breakdown; W. W. Norton \& Company: London, UK, 2008.

11. Heikkurinen, P.; Rinkinen, J.; Jarvensivu, T.; Wilén, K.; Ruuska, T. Organising in the Anthropocene: An ontological outline for ecocentric theorising. J. Clean. Prod. 2016, 113, 705-714. [CrossRef]

12. Bonnedahl, K.J.; Caramujo, M.J. Beyond an absolving role for sustainable development: Assessing consumption as a basis for sustainable societies. Sustain. Dev. 2019, 27, 61-68. [CrossRef]

13. Ruuska, T.; Wilén, K.; Heikkurinen, P. Ihminen osana luontoa: Ekologinen realismi ja kestävä taloudellinen organisoituminen (Human as part of nature: Ecological realism and sustainable economic organizing). Tiede Edist. 2019, 44, 135-149.

14. De Jonge, E. An alternative to anthropocentrism: Deep ecology and the metaphysical turn. In Anthropocentrism: Humans, Animals, Enviroments; Boddice, R., Ed.; Brill: Boston, MA, USA, 2011.

15. Heikkurinen, P.; Ruuska, T.; Wilén, K.; Ulvila, M. The Anthropocene exit: Reconciling discursive tensions on the new geological epoch. Ecol. Econ. 2019, 164, 106369. [CrossRef]

16. Bookchin, M. The Ecology of Freedom: The Emergence and Dissolution of Hierarchy; AK Press: Chico, CA, USA, 2005.

17. Heikkurinen, P. Degrowth: A metamorphosis in being. Environ. Plan. E Nat. Space 2019. [CrossRef]

18. Crutzen, P.J.; Stoermer, E.F. The Anthropocene. Glob. Chang. Newsl. 2000, 41, 17-18.

19. Barnosky, A.D.; Matzke, N.; Tomiya, S.; Wogan, G.O.; Swartz, B.; Quental, T.B.; Mersey, B. Has the Earth's sixth mass extinction already arrived? Nature 2011, 471, 51. [CrossRef]

20. Hornborg, A. The Power of the Machine: Global Inequalities of Economy, Technology, and Environment; AltaMira Press: Walnut Creek, CA, USA, 2001. 
21. Hornborg, A. Global Magic: Technologies of Appropriation from Ancient Rome to Wall Street; Palgrave Macmillan: New York, NY, USA, 2016.

22. Malm, A. Fossil Capital: The Rise of Steam Power and the Roots of Global Warming; Verso: New York, NY, USA, 2016.

23. Bauer, A.M.; Ellis, E.C. The Anthropocene divide obscuring understanding of social-environmental change. Curr. Anthropol. 2018, 59, 209-227. [CrossRef]

24. Di Chiro, G. Environmental justice and the Anthropocene meme. In The Oxford Handbook of Environmental Political Theory; Meyer, J.M., Gabrielson, T., Eds.; Oxford University Press: Oxford, UK, 2016; pp. 362-384.

25. Lövbrand, E.; Beck, S.; Chilvers, J.; Forsyth, T.; Hedrén, J.; Hulme, M.; Lidskog, R.; Vasileiadou, E. Who speaks for the future of Earth? How critical social science can extend the conversation on the Anthropocene. Glob. Environ. Chang. 2015, 32, 211-218. [CrossRef]

26. Malm, A.; Hornborg, A. The geology of mankind? A critique of the Anthropocene narrative. Anthr. Rev. 2014, 1, 62-69. [CrossRef]

27. Moore, J.W. Capitalism in the Web of Life. Ecology and the Accumulation of Capital; Verso: New York, NY, USA, 2015.

28. Ruuska, T. Capitalism and the Absolute Contradiction in the Anthropocene. In Sustainability and Peaceful Coexistence for the Anthropocene; Heikkurinen, P., Ed.; Routledge: London, UK; New York, NY, USA, 2017.

29. Archer, M.; Bhaskar, R.; Collier, A.; Lawson, T.; Norrie, A. Critical Realism: Essential Readings; Routledge: Oxon, UK, 1998.

30. Marx, K.; Engels, F. The German Ideology; Prometheus Books: New York, NY, USA, 1998.

31. Foster, J.B. Marx's Ecology: Materialism and Nature; Monthly Review Press: New York, NY, USA, 2000.

32. Naess, A. The Shallow and the Deep, Long-Range Ecology Movements. Interdiscip. J. Philos. 1973, 16, 95-100. [CrossRef]

33. Naess, A. Ecology, Community and Lifestyle; Cambridge University Press: Cambridge, UK, 1989.

34. Merleau-Ponty, M. Phenomenology of Perception; Routledge: London, UK, 2013.

35. Toadvine, T. Merleau-Ponty's Philosophy of Nature; Northwestern University Press: Evanston, IL, USA, 2009.

36. Bannon, B.E. From Mastery to Mystery: A Phenomenological Foundation for an Environmental Ethic; Ohio University Press: Athens, Greece, 2014.

37. Soper, K. What Is Nature? Culture, Politics and the Nonhuman; Blackwell: Oxford, UK, 1995.

38. Bettini, G.; Karaliotas, L. Exploring the limits of peak oil: Naturalising the political, de-politicising energy. Geogr. J. 2013, 179, 331-341. [CrossRef]

39. Daly, H.E. Beyond Growth; Beacon Press: Boston, MA, USA, 1996.

40. Heikkurinen, P.; Ruuska, T.; Kuokkanen, A.; Russell, S. Leaving Productivism behind: Towards a Holistic and Processual Philosophy of Ecological Management. Philos. Manag. 2019. [CrossRef]

41. Crutzen, P.J. Geology of mankind. Nature 2002, 415, 23. [CrossRef]

42. Waters, C.N.; Zalasiewicz, J.; Summerhayes, C.; Barnosky, A.D.; Poirier, C.; Gałuszka, A.; Cearreta, A.; Ellis, E.; Ellis, M.; Jeandel, C.; et al. The Anthropocene is functionally and stratigraphically distinct from the Holocene. Science 2016, 351, aad2622. [CrossRef]

43. Heidegger, M. The Question Concerning Technology and Other Essays; Garland Publishing: New York, NY, USA, 1977.

44. Devall, B.; Sessions, G. Deep Ecology: Living as If Nature Mattered; Gibbs Smith: Salt Lake City, UT, USA, 1985.

45. White, L., Jr. The historical roots of our ecologic crisis. Science 1967, 155, 1203-1207. [CrossRef]

46. Purser, R.E.; Park, C.; Montuori, A. Limits to anthropocentrism: Toward an ecocentric organization paradigm? Acad. Manag. Rev. 1995, 20, 1053-1089. [CrossRef]

47. Ceballos, G.; Ehrlich, P.R.; Barnosky, A.D.; García, A.; Pringle, R.M.; Palmer, T.M. Accelerated modern human-induced species losses: Entering the sixth mass extinction. Sci. Adv. 2015, 1, e1400253. [CrossRef] [PubMed]

48. Taylor, C. A Secular Age; The Belknap Press of Harvard University Press: Cambridge, MA, USA, 2007.

49. Taylor, C. Sources of the Self; Cambridge University Press: Cambridge, UK, 1992.

50. Heidegger, M. Letter on Humanism. In Basic Writings: Nine Key Essays; Routledge: London, UK, 1978.

51. Foucault, M. The Order of Things: An Archaeology of the Human sciences; Vintage Books: New York, NY, USA, 1970.

52. Foucault, M. What is Enlightenment? In The Foucault Reader; Rabinow, P., Ed.; Pantheon: New York, NY, USA, 1984; pp. 31-50.

53. Soper, K. Humanism and Anti-Humanism; Open Court Press: La Salle, MI, USA, 1986.

54. Bateson, G. Mind and Nature: A Necessary Unity; E. P. Dutton: New York, NY, USA, 1979. 
55. Krebber, A. Anthropocentrism and reason in Dialectic of Enlightenment: Environmental crisis and animal subject. In Anthropocentrism: Humans, Animals, Enviroments; Boddice, R., Ed.; Brill: Boston, MA, USA, 2011.

56. Horkheimer, M. Eclipse of Reason; Oxford University Press: New York, NY, USA, 1947.

57. Bacon, F.; Rees, G. The Instauratio Magna Part II: Novum Organum and Associated Texts; Clarendon Press: Oxford, UK, 2004.

58. Horkheimer, M.; Adorno, T. Dialectic of Enlightenment: Philosophical Fragments; Stanford University Press: Stanford, CA, USA, 2002.

59. Ruuska, T. Reproduction Revisited: Capitalism, Higher Education and Ecological Crisis; Mayfly Books: North of England, UK, 2018.

60. Benton, T. Marxism and Natural Limits: An Ecological Critique and Reconstruction. New Left Rev. 1989, 178, 51-86.

61. Biro, A. Denaturalizing Ecological Politics: Alienation from Nature from Rousseau to the Frankfurt School and Beyond; University of Toronto Press: Toronto, ON, Canada, 2005.

62. Camatte, J. The Wandering of Humanity, in This World We Must Leave and Other Essays; Autonomedia: New York, NY, USA, 1995.

63. Wendling, A. Karl Marx on Technology and Alienation; Palgrave Macmillan: London, UK, 2009.

64. De Jonge, E. Spinoza and Deep Ecology: Challenging Traditional Approaches to Environmentalism; Ashgate: Aldershot, UK, 2004.

65. WWF. Living Planet Report: Aiming Higher. 2018. Available online: https://wwf.panda.org/knowledge_ hub/all_publications/living_planet_report_2018/(accessed on 25 March 2020).

66. IPCC. Climate Change and Land: An IPCC Special Report on Climate Change, Desertification, Land Degradation, Sustainable Land Management, Food Security, and Greenhouse Gas Fluxes in Terrestrial Ecosystems. 2019. Available online: https://www.ipcc.ch/srccl-report-download-page/ (accessed on 25 March 2020).

67. Ritchie, H.; Roser, M. Land Use. 2019. Available online: https://ourworldindata.org/land-use (accessed on 25 March 2020).

68. Polanyi, K. The Great Transformation; Beacon Press: Boston, MA, USA, 1968.

69. Perelman, M. The Invention of Capitalism: Classical Political Economy and the Secret History of Primitive Accumulation; Duke University Press: London, UK, 2000.

70. Wood, E.M. The Origin of Capitalism. A Longer View; Verso: London, UK, 2002.

71. Oxfam. An Economy for the 1\%. It's Time to Build a Human Economy that Benefits Everyone, Not Just the Privileged Few. 2017. Available online: https://www.oxfam.org/sites/www.oxfam.org/files/fileattachments/ bp-economy-for-99-percent-160117-en.pdf (accessed on 25 March 2020).

72. Ulvila, M.; Wilén, K. Engaging with the Plutocene: Moving towards degrowth and postcapitalist futures. In Sustainability and Peaceful Coexistence for the Anthropocene; Heikkurinen, P., Ed.; Routledge: London, UK, 2017.

73. Kohn, M.; Reddy, K. The Stanford Encyclopedia of Philosophy. 2017. Available online: https://plato.stanford. edu/archives/fall2017/entries/colonialism/ (accessed on 25 March 2020).

74. Kohn, M.; O'Neill, D. A Tale of Two Indias: Burke and Mill on Racism and Slavery in the West Indies. Political Theory 2006, 34, 192-228. [CrossRef]

75. Traverso, E. Left-Wing Melancholia: Marxism, History, and Memory; Columbia University Press: New York, NY, USA, 2016.

76. Robinson, W.I. Global Capitalism and the Crisis of Humanity; Cambridge University Press: Cambridge, UK, 2014.

77. Lenin, V.I. Imperialism: The Highest Stage of Capitalism; Penguin Books: London, UK, 2010.

78. Foster, J.B. Late Imperialism: Fifty Years after Harry Magdoff's the Age of Imperialism; Monthly Review: New York, NY, USA, 2019.

79. Marx, K.; Engels, F. The Communist Manifesto; Penguin: London, UK, 2002.

80. Steffen, W.; Broadgate, W.; Deutsch, L.; Gaffney, O.; Ludwig, C. The trajectory of the Anthropocene: The Great Acceleration. Anthr. Rev. 2015, 2, 81-98. [CrossRef]

81. Piketty, T. Capital in the Twenty-First Century; The Belknap Press of Harvard University Press: Cambridge, MA, USA, 2014.

82. Bailey, D. The Environmental Paradox of the Welfare State: The Dynamics of Sustainability. New Political Econ. 2015, 20, 793-811. [CrossRef]

83. Kallis, G. Degrowth; Agenda Publishing: Newcastle upon Tyne, UK, 2018. 
84. Jones, D.S. Masters of the Universe. Hayek, Friedman and the Birth of Neoliberal Politics; Princeton University Press: Princeton, NJ, USA, 2013.

85. Magdoff, F.; Foster, J.B. What Every Environmentalist Needs to Know about Capitalism; Monthly Review Press: New York, NY, USA, 2011.

86. Lllich, I. Shadow Work; Marion Boyars: Boston, MA, USA, 1981.

87. Snyder, G. The Practice of the Wild; Counterpoint: Berkeley, CA, USA, 1990.

88. Gunn-Wright, R.; Hockett, R. The Green New Deal. Mobilizing for a Just, Prosperous, and Sustainable Economy. New Consensus. 2019. Available online: https://s3.us-east-2.amazonaws.com/ncsite/new_ conesnsus_gnd_14_pager.pdf (accessed on 25 March 2020).

89. Ocasio-Cortez, A. Resolution. Recognizing the Duty of the Federal Government to Create a Green New Deal. 2019. Available online: https://www.congress.gov/116/bills/hres109/BILLS-116hres109ih.pdf (accessed on 25 March 2020).

90. Klein, N. On Fire: The (Burning) Case for a Green New Deal; Simon \& Schuster: New York, NY, USA, 2019.

91. Rifkin, J. The Green New Deal: Why the Fossil Fuel Civilization Will Collapse by 2028, and the Bold Economic Plan to Save Life on Earth; St. Martin's Press: New York, NY, USA, 2019.

92. Hickel, J.; Kallis, G. Is Green Growth Possible? New Political Econ. 2019. [CrossRef]

93. Parrique, T.; Barth, J.; Briens, F.; Kerschner, C.; Kraus-Polk, A.; Kuokkanen, A.; Spangenberg, J.H. Decoupling Debunked: Evidence and Arguments Against Green Growth as a Sole Strategy for Sustainability; European Environmental Bureau: Brussels, Belgium, 2019.

94. Bhaskar, R.; Høyer, K.G.; Næss, P. Ecophilosophy in a World of Crisis: Critical Realism and the Nordic Contributions; Routledge: London, UK, 2011.

95. Vetlesen, A.J. The Denial of Nature: Environmental Philosophy in the Era of Global Capitalism; Routledge: London, UK, 2015.

96. Collier, A. Being and Worth; Routledge: London, UK, 1999.

97. Gorz, A. Ecology as Politics; Black Rose Books: New York, NY, USA, 1980.

98. Bhaskar, R. Materialism. In A Dictionary of Marxist Thought; Bottomore, T., Ed.; Blackwell: Oxford, UK, 1983.

99. Bonnedahl, K.; Heikkurinen, P. (Eds.) Strongly Sustainable Societies: Organizing Human Activities on a Hot and Full Earth; Routledge: New York, NY, USA; London, UK, 2018.

100. Georgescu-Roegen, N. Energy and economic myths. South Econ. J. 1975, 41, 347-381. [CrossRef]

101. Daly, H.E. Steady-State Economics; Island Press: Washington, DC, USA, 1991.

102. Starik, M.; Rands, G.P. Weaving an integrated web: Multilevel and multisystem perspectives of ecologically sustainable organizations. Acad. Manag. Rev. 1995, 20, 908-935. [CrossRef]

103. Mumford, L. The Myth of the Machine: Technics and Human Development; Harvest/HBJ Publishers: New York, NY, USA, 1967.

104. Latour, B. We Have Never Been Modern; Harvard University Press: Cambridge, MA, USA, 1993.

105. Latour, B. Reassembling the Social: An Introduction to Actor-Network Theory; Oxford University Press: Oxford, UK, 2005.

106. Kallis, G. Limits; Stanford University Press: Stanford, CA, USA, 2019.

107. Naess, A.; Sessions, G. A Deep Ecology Eight Point Platform. 1984. Available online: www.deepecology.org/ platform.htm (accessed on 25 March 2020).

108. Perlman, F. Against History, Against Leviathan; Black \& Red: Detroit, MI, USA, 1983.

109. Jensen, D. Endgame, Vol. 1: The Problem of Civilization; Seven Stories Press: New York, NY, USA, 2006.

110. Wapner, P. Living through the End of Nature: The Future of American Environmentalism; MIT Press: Cambridge, MA, USA, 2013.

111. Latouche, S. Farewell to Growth; Polity Press: Cambridge, UK, 2007.

112. Boehm, S.; Bharucha, Z.P.; Pretty, J. Ecocultures: Blueprints for Sustainable Communities; Routledge: New York, NY, USA, 1972.

113. Meadows, D.; Meadows, D.; Randers, J.; Behrens, W. The Limits to Growth; New American Library: New York, NY, USA, 1972.

114. Meadows, D.; Meadows, D.; Randers, J. The Limits to Growth: The 30-Year Update; Chelsea Green Publishing: Hartford, VT, USA, 2002.

115. Foster, J.B.; York, R.; Clark, B. The Ecological Rift: Capitalism's War on Earth; Monthly Review Press: New York, NY, USA, 2010. 
116. Nature Needs Half. Available online: https://natureneedshalf.org/ (accessed on 25 March 2020).

117. Helne, T.; Hirvilammi, T. Wellbeing and Sustainability: A Relational Approach. Sustain. Dev. 2015, 23, 167-175. [CrossRef]

118. Büchs, M.; Koch, M. Postgrowth and Wellbeing Challenges to Sustainable Welfare; Palgrave Macmillan: London, UK, 2017.

119. Buch-Hansena, H.; Koch, M. Degrowth through income and wealth caps? Ecol. Econ. 2019, 160, $264-271$. [CrossRef]

120. Heikkurinen, P. Degrowth by means of technology? A treatise for an ethos of releasement. J. Clean. Prod. 2018, 197, 1654-1665. [CrossRef]

(C) 2020 by the authors. Licensee MDPI, Basel, Switzerland. This article is an open access article distributed under the terms and conditions of the Creative Commons Attribution (CC BY) license (http://creativecommons.org/licenses/by/4.0/). 